\title{
Knowledge, Policy, Action in the Decade of Nutrition 2016-2025
}

\section{What is working or not? Where are the gaps? What needs more effort or change?}

\author{
Margaret Miller \\ President, World Public Health Nutrition Association \\ Convenor WPHN Congress 2020
}

\section{Background}

Today, nearly one in three persons globally suffers from under-nutrition, micronutrient deficiency, overweight and/or obesity (Food and Agriculture Organization et al, 2018; Development Initiatives, 2018) - and diet-related non-communicable diseases (NCDs) affect a large part of the world's population (NCD Countdown 2030 collaborators, 2018). Overall, poor diet is a factor in one in five deaths worldwide (GBD 2016 Causes of Death Collaborators, 2017). These different forms of malnutrition co-exist - within the same country (Development Initiatives, 2018), community (Tzioumis and Adair, 2014), household (Aitsi-Selmi, 2015; Raskind et al, 2018) or individual (Gosdin et al, 2018; Jones et al, 2017). The causal factors are complex and multidimensional and the impacts of sub-optimal nutrition on development, society, health and well-being are serious and lasting, for individuals and their families, for communities and for countries (Swinburn et al, 2019; Webb et al, 2018).

Global food production is the largest pressure exerted by humanity on this planet, threatening local ecosystems and natural cycles such as carbon, water, nitrogen and others that stabilise the "Earth system” (Tilman and Clark, 2014; Global Panel on Agriculture and Food Systems for Nutrition, 2016; Willett et al, 2019). Current dietary patterns and nutrition transition, combined with projected population growth to about 10 billion by 2050, will accelerate risks to people and planet (Popkin et al, 2012; Alexandratos \& Bruinsma, 2012; Godfrey et al, 2010). The global burden of NCDs is predicted to increase (NCD Countdown 2030 collaborators, 2018) and the effects of food production on greenhouse-gas emissions (Poore and Nemecek, 2018; Vermeulen et al, 2012), nitrogen and phosphorus pollution (Diaz and Rosenberg, 2008; Sutton et al, 2013), biodiversity loss (Tilman et al, 2017; Sala et al, 2000), and water (Von Braun et al, 2017) and land use (Von Braun et al, 2017; Foley et al, 2005) will be exacerbated. Unhealthy and unsustainably produced food therefore poses a global risk to people and the planet.

Climate change is looming both as a cause and consequence to considerably compound these health and food production challenges (Myers et al, 2017; Springmann et al, 2016). Recent reviews have suggested that climate change, obesity and under nutrition have common system drivers, including car-oriented transport systems and high consumption of cheap energy sources both as food and for agricultural and industrial purposes (Swinburn et al, 2019; Willett et al, 2019).

There are many calls for action to address these issues at every level (WHO, 2013; FAO, 2014; UN, 2015a; UN, 2015b; HLPE on Food Security and Nutrition, 2017; Caron et al, 2018; Swinburn et al, 2019; Willett et al, 2019). The UN Sustainable Development Goals (SDGs) (UN, 2015a) seek to end hunger and malnutrition as well as poverty and other determinants which directly or indirectly impact nutrition and environment. 
In 2016 the UN General Assembly proclaimed 2016-2025 as the Decade of Action on Nutrition (UN General Assembly, 2016), with the aim to accelerate implementation of the ICN2 commitments (FAO, 2014), achieve the Global Nutrition and diet-related NCD targets by 2025, and contribute to the realisation of the SDGs by 2030. The associated work plan and action (UN, 2017) is centered on six cross cutting, integrative areas for impact, derived from the ICN2 recommendations and relevant to related SDGs. As we approach the mid-point of this decade, there is need to pause to reflect on how we are progressing in our efforts to address public health nutrition issues across the world, to discuss our successes and failures and to consider where to next.

\section{World Public Health Nutrition Congress 2020}

The World Public Health Nutrition Association (WPHNA) will hold its third World Public Health Nutrition Congress in Brisbane, Australia 31 March to 2 April 2020. (WPHN Congress 2020, nd). The overarching theme of the Congress will address the current state of knowledge, policy and action in public health nutrition at the mid-point of the Decade of Nutrition, and ask the questions: What is working or not? Where are the gaps? What needs more effort or change?

Sub-themes for the Congress are drawn from the six Action Areas for the Decade of Action on Nutrition (UN, 2017), with capacity development for public health nutrition action identified as a seventh theme fundamental to WPHNA functions. The seven themes will provide content streams that progress from knowledge to policy and action across the three main days of the Congress. Working Groups in each stream will prepare pre-congress issues papers and collate recommendation and outcomes from the Congress. Our aim is to identify priority issues from each sub-theme that will become the focus for WPHNA policy, advocacy and action following the Congress.

The Congress program is designed to provide lively and productive discussions and contributions from people engaged in public health nutrition and related fields. As with previous WPHNA Congresses, there will be an emphasis on sharing between and within the global north and south to identify key knowledge, effective policies and actions. The South East Asia and Pacific region will be a focus, but with emphasis on knowledge translation and learning from the global community.

\section{World Nutrition}

Leading up to the Congress, the Association journal, World Nutrition, will publish the Congress Working Group issues papers and invite readers to comment in letters to the editor. Readers and congress participants are also invited to contribute papers relevant to the themes to a special issue of this journal. The lead author of one paper each submitted by November 302019 from low or lowmiddle income countries from Asia/Pacific, Africa and Latin America will be awarded conference fees, airline tickets, and hotel costs for attending the Congress.

\section{Box 1. Action Areas for the UN Decade of Action on Nutrition 2016- 2025}

1. $\quad$ Sustainable, resilient food systems for healthy diets;

2. Aligned health systems providing universal coverage of essential nutrition actions;

3. Social protection and nutrition education;

4. Trade and investment for improved nutrition;

5. $\quad$ Safe and supportive environments for nutrition at all ages; and

6. Strengthened governance and accountability for nutrition.

Note: WPHN Congress 2020 will include an additional theme: Capacity development for public health nutrition action 


\section{References}

Alexandratos N, Bruinsma J. 2012. World Agriculture Towards 2030/2050 The 2012 Revision. ESA Working Paper No. 12-03 June 2012. Rome: Agricultural Development Economics Division, FAO. http://www.fao.org/3/a-ap106e.pdf

Caron P, de Loma-Osorio GF, Nabarro D, et al. 2018. Food systems for sustainable development: proposals for a profound four-part transformation. Agronomy and Sustainable Development 38(4):41. doi: 10.1007/s13593-018-0519-1.

Diaz RJ, Rosenberg R. 2008. Spreading dead zones and consequences for marine ecosystems. Science 321: 926-29. doi: 10.1126/science.1156401.

FAO. 2014. The Second International Conference on Nutrition: committing to a future free of malnutrition. Rome: Food and Agriculture Organization of the United Nations.

Foley JA, Defries R, Asner GP, et al. 2005. Global consequences of land use. Science 309:570-74. DOI: $10.1126 /$ science.1111772

Global Panel on Agriculture and Food Systems for Nutrition. 2016. Food systems and diets: Facing the challenges of the 21st century. London, UK:Global Panel. https://www.glopan.org/foresight

Godfray HCJ, Beddington JR, Crute IR et al. 2010. Food Security: The Challenge of Feeding 9 Billion People Science 327 (5967), 812-818. doi:10.1126/science.1185383.

HLPE on Food Security and Nutrition. 2017. Nutrition and food systems. A report by the High Level Panel of Experts on Food Security and Nutrition of the Committee on World Food Security. Rome:Food and Agriculture Organisation. http://www.fao.org/3/a-i7846e.pdf

Myers SS, Smith MR, Guth S, et al. 2017. Climate change and global food systems: potential impacts on food security and undernutrition. Annual Review Public Health 38:259-77. doi: 10.1146/annurevpublhealth-031816-044356

Poore J, Nemecek T. 2018. Reducing food's environmental impacts through producers and consumers. Science 360:987-92. doi:10.1126/science.aaq0216.

Popkin BM, Adair LS, Ng SW. 2012. Global nutrition transition and the pandemic of obesity in developing countries. Nutrition Reviews 70:3-21. doi: 10.1111/j.1753-4887.2011.00456.x.

Sala OE, Chapin FS, Armesto JJ, et al. 2000. Global biodiversity scenarios for the year 2100. Science 287: 1770-74. doi:10.1126/science.287.5459.1770.

Springmann M, Mason-D’Croz D, Robinson S, et al. (2016) Global and regional health effects of future food production under climate change: a modelling study. Lancet 387:1937-46. doi: 10.1016/S0140-6736(15)01156-3.

Sutton MA, Bleeker A, Howard CM, et al. 2013 Our nutrient world: the challenge to produce more food and energy with less pollution. Global Overview of Nutrient Management. Edinburgh: Centre for Ecology and Hydrology, \& United Nations Environment Programme.

http://nora.nerc.ac.uk/id/eprint/500700/

Tilman D, Clark M. 2014. Global diets link environmental sustainability and human health. Nature 515:518-22. doi: 10.1038/nature13959. 
Tilman D, Clark M, Williams DR, et al. 2017. Future threats to biodiversity and pathways to their prevention. Nature 546:73-81. doi:10.1038/nature22900.

United Nations. 2017. UN Decade of Action on Nutrition (2016-2025) Work Programme https://www.unscn.org/uploads/web/news/Work-Programme UN-Decade-of-Action-on-Nutrition20170517.pdf

United Nations. 2015a. Resolution adopted by the General Assembly on 25 September 2015. 70/1. Transforming our world: the 2030 Agenda for Sustainable Development. New York: United Nations. https://www.un.org/en/development/desa/population/migration/generalassembly/docs/globalcompact/ A_RES_70_1_E.pdf

United Nations. 2015b. Paris Agreement United Nations Framework Convention on Climate Change. https://unfccc.int/sites/default/files/english_paris agreement.pdf

United Nations General Assembly. 2016. Resolution adopted by the General Assembly on 1 April 2016 [without reference to a Main Committee (A/70/L.42 and Add.1)] 70/259. United Nations Decade of Action on Nutrition (2016- 2025) https://www.un.org/en/ga/search/view_doc.asp?symbol=A/RES/70/259

Vermeulen SJ, Campbell BM, Ingram JSI. 2012. Climate change and food systems. Annual Review Environmental Resources 37:195-222. doi:10.1146/annurev-environ-020411-130608.

Von Braun J, Gulati A, Kharas H. 2017. Key policy actions for sustainable land use and water use to serve people. Economics 11:1-13. doi.org/10.5018/ economics-ejournal.ja.2017-32

WHO. 2013. Global action plan for the prevention and control of NCDs 2013-2020. Geneva: World Health Organization. https://www.who.int/nmh/events/ncd action_plan/en/

WHO. 2018. Decade of action on nutrition - the April 2016 proclamation. World Health Organization. http://www.who.int/nutrition/decade-of-action/information_flyer/en/

Willett W, Rockström J, Loken B et al. 2019. Food in the Anthropocene: the EAT-Lancet Commission on healthy diets from sustainable food systems. Lancet 393(10170):447-492. doi: 10.1016/S0140-6736(18)31788-4.

WPHN Congress 2020 (nd) https://www.wphncongress2020.com/ 